\title{
Private Pension Plans: An Important Component of the Financial Market
}

\author{
Mirela Cristea ${ }^{1}$, Eleftherios Thalassinos ${ }^{2}$
}

\begin{abstract}
:
One of the European financial market's components is the pension fund, which does not represent a common scheme valid in all member-states. Each member-state has established a specific scheme being in accordance with other financial and working characteristics as well as in accordance with social, economic and political aspects of the economy.

This article analyses the main components of the private pension market in the European Union, as part of the financial market and in comparison with other issues by presenting comparative pension systems beeing established by a number of countries in the EU.

It also presents their structure, their asset management, the financial risks associated with and the methods of counteracting them.
\end{abstract}

Key Words: pention plans, social benefits, unemployment compensation.

\footnotetext{
${ }^{1}$ University of Craiova, Romania

${ }^{2}$ University of Piraeus, Greece, thalassinos@ersj.eu
} 


\section{Introduction}

Most of the EU's pension systems have been organized after the multi-pillar traditional classification proposed by the World Bank in 1994 consisting of four pillars depending on the paying part.

The first pillar is based on the public pension scheme regulated by each country according to its macroeconomic figures. The second pillar is based on the occupational pension scheme which is related to the worklife of each employee as it has been determined by the employment contracts. The third pillar is based on individual provisions unrelated to occupation based on the economic ability of each employee to pay.

Depending on the stage of growth of their pension systems, EU's member-states have decided structural reforms at different levels, nature and size in an attempt to improve the effectiveness of the systems and make them sustainable for a longer period. Four different groups of countries have already been formed based on the system they have followed:

1. Countries with less developed private pension schemes, which do not intend to change the structure, although they have presented a trend in this respect. Three European countries are very close to this group namely Spain, Greece and France.

2. Countries with well-developed private pension schemes, which have always relied on these systems. These countries are Denmark, the Netherlands and the United Kingdom, although United Kingdom is in a process of exit from EU nowdays.

3. Countries with public pension systems, pay-as-you-go, reformed respectively by introducing the second pillar, which is actually a mandatory pillar. In this group of countries are Bulgaria, Estonia, Latvia, Lithuania, Hungary, Poland, Romania and Slovakia.

4. Countries with unfunded, however traditional social insurance schemes, sometimes along with a minimum social insurance compensation. This group of countries has already adopted a totally private pension scheme. In this group of countries are Germany, Austria and Italy.

\section{Pension System Components}

European pension plan systems include the following three components. One component regulated by law, which finances the public pension pillar entirely with a paying quota by the responsible organization which has been established for this reason in all countries and the social security contributions paid by the participants at 
the public pension's organization. This component applies in countries such as Bulgaria, Estonia, Lithuania, Latvia, Hungary, Poland, Romania and Slovakia.

A second pension component established by the employment contracts (collective or individual employment stipulations), also called occupational pensions, which is common in countries such as Bulgaria, Poland and Slovenia.

A third component which is actually an individual account belonging to a profession. This account is used by registered members in each profession, the majority of the participants in this account are employed, however collective membership being possible as well especially through unions or associations. The participation in this component is optional and it is found in the following countries: Czech Republic, Latvia, Romania and Slovakia.

In EU there is not a common pension scheme valid for all member-states. In fact there are different pension schemes depending on public's financial strenth to support the system. In general a pension system in Europe includes the state component which is supplemented mainly by two or more components of private pension funds.

European member-states had different periods of implementation for the private pension components, so they are either in the phase of accumulation of the contributions required or in the process of payment of benefits the so called pension allowances.

\section{Financial Risks behind the Private Pension Systems}

Regarding the financial risks of the private pension systems, there are different ways of managing the private pension funds' assets and the precisely strategies of their investments, by imposing certain guarantee mechanisms.

European pension fund management, traditionally, has been closely based on domestic bonds investments. Especially in Spain, Germany and France, there was mistrust in international investment, for example, due to concerns about currency risk, liquidity and lack of information.

Nowadays, although the European Union has already established a comprehensive set of prudential rules for banks, insurance companies, investment companies and investment funds, pension funds organizations remained the only major financial organization which is exclusively regulated at national level.

But, even if there are not common prudential rules, applicable in all member-states in EU, some pension funds which are subject to authorization or approval by a competent authority can be identified. These pension funds can be recognized by 
establishing a set of criteria for authorizing or approving funds, such as the legal form of funds, the administrators' professionalism etc.

In addition they impose the rules of pension funds supervision, the regular standard reporting and the control jurisdiction of the competent authority. At the same time they approve the rules for the investment policy of the pension funds organization.

Pension funds investments in some member-states have imposed restrictions on the ways and methods how they can invest their net assets. Some member-states have set up a variety of rigid regulatory limits in pension funds organizations such as:

- $\quad$ rules requiring a minimum investment in government bonds or government capital projects, for example, in dwelling buildings. For a long time, France has imposed a minimum holding rate of pension fund assets in securities summing to half of them;

- rules to limit holdings on assets with relatively volatile revenue such as shares, bonds, real estate and foreign assets. For example, Germany has restricted investment in shares at the companies located in the European Union, up to $30 \%$ of net assets.

\section{EU Proposal for Private Pension Systems}

EU Directives aim to improve investment performance by eliminating rules to the absolute minimum necessary to properly protect pension funds and their beneficiaries. Another objective of EU Directives is the process for assets' diversification, including diversification into assets denominated in other currencies than those in which the liabilities of pension funds are established.

In present conditions, where public pension funds are facing an acute lack of reserves due to the aging of the population, the issue of financial stability has been increased despite of any method applied for pension funds calculation.

\section{Counteraction Methods for the Financial Risks of the Private Pension System}

By legislation, most EU member-states in Central and Eastern Europe have introduced various measures to minimize the risks arising from investment, by restrictions imposed on some elements of pension schemes, such as:

- types of financial instruments;

- the structure of portfolio investment;

- geographical and foreign exchange restrictions;

- guarantees, particularly those of real rates of return. 
For example countries such as Slovakia, Poland and Bulgaria have a mechanism regarding the profitability that states a relative rate of return - a regulated rate of return compared to a target, a certain level predetermined, but administrators are tempted to adopt similar structures of portfolios, leading to achieving that target.

Other countries such as Estonia, Hungary, Lithuania, Poland, Romania and Slovakia have established safeguards in case of inefficient fund management. Also, the specific legal provisions have established regular payments into a guarantee fund, which is available only for the participants in order to cover losses from these funds.

\section{Conclusions}

Pension plan systems around the world are facing many difficulties. In particular in public pensions the component related to reducing dependency (ie the decreases in the number of contributors and the pensioners increases), due to an aging population problem coupled with the declining trend in birth rates.

Regardless of the organization of the pension system, for the two core components of it, namely the public pension scheme and the private pension scheme, have developed numerous studies and analyzes regarding the identification of possible solutions tackling the problems. Especially the public pension plan which is aiming at the value evolution of private pension assets under the influence of certain factors and their efficient allocation to investments that lead to high yields, by applying the uniform regulatory and guaranteed schemes.

European Commission representatives argue that, once the states have undertaken to implement structure reforms, they must maintain the system adopted, regardless of the economic situation in the country. EU intervention regarding the architecture of the pension plan system in member-states is limited, due to different cultures, ethics, social and economic characteristics, macroeconomic figures and of course because of the different priorities set by the government in each country with regard to the objective of the pension plan system, its own characteristics and the rules of the pension's plan system management.

Thus, each member-state shall establish and implement its investment policy of pension funds, the restrictions on them as the EU Directives have designed to improve performance by eliminating investments to the absolute minimum necessary regulation.

Regarding pension fund assets around the world, their value has been greatly reduced during the current economic and financial crisis, which caused a reallocation of investment of pension fund assets to low risk investments, mainly oriented to domestic investment, especially in countries of the Organisation for Economic Co-operation and Development. 
In other countries the exchange rate appreciation caused an increase in the assets of private pension funds. There is an extended research analyzing the effects of selected factors on the assets of private pension systems. For the case of the private pension system in Romania, it has been shown that the evolution of the interest rate loans, the monetary policy rate and the index BET-C have influenced the privately managed pension fund assets reducing the value of their assets significantly.

Exchange rate affects privately managed pension fund assets in the attempt to increase them. In order to counteract the effects of a decrease of the net asset value of pension funds, it is required to develop a mix of their placements on a short term period, dynamic and adaptable to the variations of the influencial factors. This will create opportunities for better yields on pension funds and will prevent a decrease of the contributions of the participants to these pension funds.

\section{References}

Thalassinos, I.E. and Pociovalisteanu, M-D. (2009). The Structural Funds and the Economic and Social Cohesion Process. Annals-Economy Series 1, 313-330.

Thalassinos, I.E., Deceanu, L. and Pintea, M. (2010). New Dimensions of Country Risk in the Context of the Current Crisis: A Case Study for Romania and Greece. European Research Studies Journal, 13(3), 225-236.

Thalassinos, E. and Liapis, K. (2013). A Comparative Analysis for the Accounting Reporting of Employee Benefits between IFRS and other Accounting Standards: A Case Study for the Biggest Listed Entities in Greece. International Journal of Economics and Business Administration, 1(1), 99-124.

Thalassinos, I.E. and Liapis K. (2014). Segmental financial reporting and the internationalization of the banking sector. Chapter book in, Risk Management: Strategies for Economic Development and Challenges in the Financial System,(eds), D. Milos Sprcic, Nova Publishers, 221-255, ISBN: 978-163321539-9; 978163321496-5.

Thalassinos I.E. and Dafnos G. (2015). EMU and the process of European integration: Southern Europe's economic challenges and the need for revisiting EMU's institutional framework. Chapter book in Societies in Transition: Economic, Political and Security Transformations in Contemporary Europe, 15-37, Springer International Publishing, DOI: 10.1007/978-3-319-13814-5 2.

Thalassinos, I.E., Pintea, M., Raţiu, I.P. (2015). The Recent Financial Crisis and Its Impact on the Performance Indicators of Selected Countries during the Crisis Period: A Reply. International Journal of Economics and Business Administration, 3(1), 3-20. 